\title{
A Study of the Perceived Service Quality and its Dimensions in Private Sector Banks
}

\author{
${ }^{1}$ Mukta Dewan, ${ }^{2}$ Dr SadhanaMahajan \\ ${ }^{1}$ Research Scholar, Faculty of Commerce and Management Studies, Himachal Pradesh University Business \\ School, Shimla - 171005, India. \\ ${ }^{2}$ Professor, Faculty of Commerce and Management Studies, Himachal Pradesh University Business School, \\ Shimla - 171005, India.
}

\begin{abstract}
The purpose of conducting this research was to explore how the customers of the private sector banks perceive the various dimensions of service quality. This research was mainly based on primary data which had been collected through a well-structured questionnaire (adapted from the PZB model of service quality). The questionnaire had been distributed to 300 respondents. This paper makes a useful contribution as there are very low number of studies that have been conducted in India on such dimensions like tangibility, reliability, responsiveness assurance and empathy. This research showed that perception of service quality varies from person to person and, bank managers need to conduct more researches in order to evaluate perceived service quality more strongly.
\end{abstract}

Keywords: Service quality, dimensions, demographics, Private Banks.

\section{Introduction}

Service sector is the lifeline for the social economic growth of a country. It is today the largest and fastest growing sector globally contributing more to the global output and employing more people than any other sector. For most countries around the world, services are the largest part of their economy. The real reason for the growth of the service sector is due to the increase in urbanization, privatization and more demand for intermediate and final consumer services. Availability of quality services is vital for the well being of the economy. The Indian Service sector covers a wide range of activities, such as transportation, communication, trading, finances, real estate and health, among others. Amongst these India's financial sector is diversified and is expanding rapidly. It comprises of commercial banks, insurance companies, non-banking financial companies, mutual funds and other smaller financial entities. Ours is a bank dominated financial sector and commercial banks account for over 60 per cent of the total assets of the financial system. Indian Banking sector forms the backbone of the country's economy.

After nationalisation of banks in 1969 public sector banks came to occupy dominant role in the banking structure. Private sector banking in India received a flip in 1994 when Reserve Bank of India encouraged setting up of private banks as part of its policy of liberalisation of the Indian Banking Industry. Housing Development Finance Corporation Limited (HDFC) was amongst the first to receive an 'in principle' approval from the Reserve Bank of India (RBI) to set up a bank in the private sector. Private Banks have played a major role in the development of Indian banking industry. They have made banking more efficient and customer friendly. In the process they have jolted public sector banks out of complacency and forced them to become more competitive. In these banks most of the shares are in the hands of private owners.

Like any other financial services, the banking industry, too, is facing a market that is changing rapidly. New technologies are being introduced and there is always a fear of economic uncertainties. In developing countries like India, it has become very important that banks determine the service quality factors, which are pertinent to the customer's selection process, as with increased competition, with the advent of international banking, the trend towards larger bank holding companies, and innovations in the marketplace, customers are now having greater difficulty in selecting one institution from another. In order to provide excellent service quality, identifying the underlying dimensions of the service quality construct is the first step in the definition and hence provision of quality service and thus should be a central concern for retail bank managers as well as service management academicians and practitioners. Maintaining effective customer service helps to build and maintain customer relationship that is the key success in current banking scenario. Better service quality typically can help to get higher market share and better returns (Slu \& Mou 2003). It is desirable for service providers to uncover what attributes consumers utilized in their assessment of overall service quality. 


\subsection{Service Quality}

\section{Literature Review}

According to Parasuraman, Zeithaml\& Berry (1988) service quality is the customer's judgment of overall excellence of the service or the difference between customer's expectation and the actual service performed or perceived. Gronroos (1984) defines perceived service quality as a consumption process in which the customer is part of the service process that leads to an outcome or result. The way the customer perceives the service process at the time of the service is more important than the outcome of the service. The customer's expectation and perception of the service becomes important when the customer thinks back to see if the perception exceeded the expectations (Siu\& Cheung 2001,Kang\& James, 2004).

Parasuraman, Zeithaml\&Berry(PZB) (1988) developed a service quality model and termed it as gap model . The gap model is about giving managers the tools to improve service quality. The consumer gap is the difference between the customer's expectations of the services and the perception of the services. To measure it a 22 item scale called SERVQUAL(Service Quality) was used. SERVPERF(Service performance) is similar to SERVQUAL, in that it uses the same 22 item scale to measure service quality, but differs in the number of times the service quality is measured. SERVPERF(Cronin and Taylor 1992) uses the 22 item scale once to measure the perception of service quality; whereas the SERVQUAL uses the scale twice once to measure the expected service quality and once to measure the perceived service quality.

\subsection{Measuring Service Quality}

SERVQUAL is used to measure service quality as a multi-dimensional construct across five dimensions: tangibility, reliability, responsiveness, assurance and empathy (Cui, Lewis \& Park, 2003). The five dimensions are explained in detail below:

Tangibility: the physical appearance of the facility which includes materials, equipment and personnel. This enhances the image of the company and provides a more positive image in the way the customer perceives the service.

Reliability: this refers to service reliability, which is different from product reliability and involves the service provider to be able to perform the services accurately and dependably. This means that the company fulfils its promises with regard to the delivery of the service, the price and solving the customer's problems.

Responsiveness: the readiness to provide timely service by the service provider. This includes paying attention to the customer, and dealing with the customer's complaints and problems in a timely manner. Responsiveness is being flexible with the customer and trying to accommodate the customer's demands and performing the service without delay.

Assurance: the ability to deliver services at a professional level. This includes the employee's knowledge and courtesy which inspires confidence in them. Having trust and confidence in the employee leads to the customer having more trust in the company itself. For example, a salesman who sells health insurance needs the customer's trust, in order for them to buy the health insurance (Wilson et al., 2008).

Empathy: the ability to understand customer needs and to give personal attention. This includes the ability to show the customer that the service provider cares about him/her because they know how valuable s/he is to the business. It is being able to build a relationship with the customer, understanding their needs and providing him/her with personalized services.

Badri M, (2003) made an assessment and application of the SERVQUAL model in measuring service quality in information technology centre. For their research gap they used a larger sample which also differs from other studies that addressed the dimensionality problem of the IT centre-adapted SERVQUAL instruments.

Curry et al., (2002, p.197) in an attempt to assess the quality of physiotherapy services used the SERVQUAL model and three physiotherapy services in Dundee, Scotland. They considered the ten original criteria for evaluation and combined them into five; tangibles, reliability, responsiveness, assurance (including competence, courtesy, credibility, and security) and empathy (including access, communication, and understanding).

Avkiran (1999) used service quality instrument developed in Australia to measure service quality in retail banking as perceived by customers (BANKSERV). It was adapted from SERVQUAL to specifically suit the Australian banking industry.

Wang et al. (2002) found in Chinese banks that reliability was the key drivers of the product quality \&followed by tangibility. The authors argued in favour of improving service quality \&product quality to build and enhance company reputation.

Huseyin Arasli, SalimeMehtap-Smadi and SalihTuranKatircioglu (2005) measured the service quality perceptions of Greek Cypriot bank customers. Author found that the expectations of bank customers were not met where the largest gap was obtained in the responsiveness-empathy dimension.

Zanna et al. (2009), analyzed the service quality of the customer contact centres of various organizations in Netherland. They modified the SERVQUAL scale and found that perceived customer contact centre quality 
consisted of seven dimensions: reliability, empathy, customer knowledge, customer focus, waiting cost, user friendliness of the voice response unit, and accessibility.

Yaghi Derar Shaker (2010) measured the retail service quality in a college shop. This scale was modified as the retail service quality scale (RSQS) to make it more contexts specific and culturally sensitive for the retail college shop (Al Waha) at Dubai Women's College.

Rai (2009) identified tangibility (seating, lighting, signage, and parking) competence (Knowledge and ability), responsiveness (willingness and adherence), safety (confidence), communication (content and quality) and understanding customers (approach towards customer) as important dimensions of service quality.

Kumar and Mani (2010) undertook a study involving 22 item of Servqual with additional 4 items relating to the dimension of convenience. The response was taken related to expectations and perceptions of the customer.

Negi, (2009, p.31-38) used the model to determine perceived quality in the Telecommunication industry and found out that reliability, empathy and network quality proved to significantly effective in contributing to overall service quality.

\subsection{Moderating effect of Demographics on the perception of Service Quality}

Demographic information allows researchers to obtain characteristics of their sample therefore making the classification of the data more meaningful (Elanain, 2003). Demographic information such as age, gender and education level need to be examined when measuring service quality in retailing; in order to discover the relationship between demographic information and dimensions (Siu\& Cheung, 2001).

According to Ganesan-Lim, Russell-Bennett \& Dagger (2008) it is important to understand the relationship between the customer's perception of service quality and demographic information such as age, gender and income level. This information is useful for ensuring there are suitable products available for the target market.

Research suggests that demographics do have an effect on some service quality dimensions such as the reliability dimension (Paulins, 2005). According to Meng et al (2009) demographic information shows that customers with different demographic characteristics have different perceptions of service quality.

Spathis et al. (2004) studied the service quality of Greek banks on the basis of customers' perceptions. They also analyzed effects of gender on customers' perception of service quality dimensions such as effectiveness and assurance, access, price, tangibles, service portfolio and reliability.

According to Ogden \& Ogden (2005) the most important demographic information is 'marital status' because it shows if customers are buying for themselves, for a spouse, or a family with children. Education level is an important demographic information because as customers 'become more educated they demand different products and different levels of service (Kent \& Omar, 2003).

Kotler\& Armstrong (2010) suggest there has been an increase in educated people in the United States and this leads to an increase in the demand for quality products.

\section{Model and Hypotheses}

\begin{tabular}{|c|c|c|}
\hline Dimensions - & & Demographics \\
\hline Tangibility & Perceived & Gender \\
\hline Reliability & Service & Age \\
\hline Responsiveness & Private sector & Income \\
\hline Assurance & Banks & Education \\
\hline \multirow[t]{2}{*}{ Empathy } & & Occupation \\
\hline & & Marital Status \\
\hline Figure 1.Researc & erceived ser & d its dimensions \\
\hline
\end{tabular}

\section{Hypotheses}

The study considered the moderating effect of variables which included 6 demographic factors: (i) Gender (ii) Age (iii) Income (iv) Education (v) Occupation (vi) Marital Status. The review of literature indicated that the customers differ in their perception of service quality and its dimensions. The difference in the perception may be due to some demographic factors. The hypotheses were formulated as under: 
H1.1: There would be a significant difference in the perceived Service quality and its various dimensions for private bank customers on the basis of gender.

H1.2: There would be a significant difference in the perceived Service quality and its various dimensions for the private bank customers on the basis of age.

H1.3: There would be a significant difference in the perceived Service quality and its various dimensions for the private bank customers on the basis of income.

H1.4: There would be a significant difference in the perceived Service quality and its various dimensions for the private bank customers on the basis of educational backgrounds.

H1.5: There would be a significant difference in the perceived Service quality and its various dimensions for the private bank customers on the basis of Occupation.

H1.6: There would be a significant difference in perceived Service quality and its various dimensions for the private bank customers on the basis of marital status.

\section{Methodology}

The research has been conducted in the tricity region of Chandigarh, Panchkula and Mohali. The three branches of HDFC Bank with 300 customers have been selected for the present study through convenient sampling technique and data and information pertain to the year 2012-2013.The service quality is assessed based on Parasuraman, et. al.,'s (1988) five dimensions namely, tangibility, reliability, responsiveness, assurance and empathy. The questions for measuring the service quality were taken from a standardized scale SERVPERF (Cronin \& Taylor (1994)).All questions are measured on 5-point likert scale where "1=strongly disagree", " $2=$ disagree", " $3=$ neutral", " $4=$ agree", and " $5=$ strongly agree". In order to accomplish the objectives, T-test and Anova have been applied.

\subsection{The Demographic characteristics of customers}

\section{Results and Discussions}

The demographic characteristics of customers of the private sector bank were analysed and the results are presented in Table-1. Results of description showed that the HDFC bank sample consists of greater percentage of males customers (59.9\%) than female customers. Majority of the respondents/customers (77\%) were in the age group 25-40 years .Most of the customers were Post graduates (80.6\%). Majority of the respondents belonged to the salaried class $(88.1 \%)$. Most of the customers had an annual income of up to 5 lacs $(56 \%)$.The respondent of the HDFC Bank had a greater percentage of married customers (65.1\%) than the unmarried customers.

\subsection{Difference in the perceived service quality and its dimensions for HDFC Bank customers on the basis of Gender}

To find out whether there was any difference in the perception of male and female customers of HDFC Bank, independent $\mathrm{t}$-test was performed (Table-2). Since the $\mathrm{t}$-value is greater than the table value for all the dimensions of service quality except for tangibility, the perception of male and female customers vary significantly for all the dimensions, namely: reliability, responsiveness, assurance and empathy. Thus hypothesis H1.1 pertaining to significant difference based on age was accepted for all the dimensions of service quality except for tangibility.

\subsection{Difference in the perceived service quality and its dimensions for HDFC Bank customers on the basis} of Age

Table-3 depicts the Analysis of Variance based on age for service quality and its dimensions. The calculated value of $\mathrm{F}$ is more than the table value for tangibility, responsiveness and empathy. Hence, H1.2 for significant difference based on age was partially accepted for the dimensions tangibility, responsiveness and empathy.

Table-1 Demographic Characteristics of the Customers

\begin{tabular}{|l|c|c|}
\hline Particulars & Frequency & Percent \\
\hline Gender & & 59.9 \\
\hline Male & 151 & 40.1 \\
\hline Female & 101 & \\
\hline Age & & 15.1 \\
\hline$<25$ yrs & 38 & 77.0 \\
\hline $25-40$ yrs & 194 & 7.9 \\
\hline$>40$ yrs & 20 & 56.0 \\
\hline Annual Income & & \\
\hline Upto 5 lacs & 141 & \\
\hline
\end{tabular}


A Study of the Perceived Service Quality and its Dimensions in Private Sector Banks

\begin{tabular}{|l|c|c|}
\hline 5 lac-15lac & 93 & 36.9 \\
\hline$>15$ lac & 18 & 7.1 \\
\hline Education & & 19.4 \\
\hline Graduate and below & 49 & 80.6 \\
\hline Post Grad and above & 203 & \\
\hline Occupation & 222 & 88.1 \\
\hline Salaried & 6 & 2.4 \\
\hline Business & 14 & 5.6 \\
\hline Retired & 10 & 4.0 \\
\hline Student & & 65.1 \\
\hline Marital Status & 164 & 34.9 \\
\hline Married & 88 & \\
\hline Unmarried & & \\
\hline
\end{tabular}

Table-2: T-test for the difference in the perceived service quality and its dimensions for HDFC Bank customers on the basis of gender

\begin{tabular}{|c|c|c|c|c|c|}
\hline \multicolumn{6}{|l|}{ Group Statistics } \\
\hline & Gender & $\mathrm{N}$ & Mean & Std. & t-value \\
\hline \multirow[t]{2}{*}{ Tangibility } & Male & 151 & 15.52 & 3.332 & \multirow{2}{*}{0.640} \\
\hline & Female & 101 & 15.24 & 3.672 & \\
\hline \multirow[t]{2}{*}{ Reliability } & Male & 151 & 19.99 & 3.570 & \multirow[t]{2}{*}{$2.228 *$} \\
\hline & Female & 101 & 18.90 & 4.100 & \\
\hline \multirow[t]{2}{*}{ Responsiveness } & Male & 151 & 7.75 & 2.740 & \multirow[t]{2}{*}{$2.395 *$} \\
\hline & Female & 101 & 6.93 & 2.582 & \\
\hline \multirow[t]{2}{*}{ Assurance } & Male & 151 & 12.03 & 2.574 & \multirow[t]{2}{*}{$2.294 *$} \\
\hline & Female & 101 & 11.21 & 3.054 & \\
\hline \multirow[t]{2}{*}{ Empathy } & Male & 151 & 17.11 & 2.887 & \multirow[t]{2}{*}{$3.475^{*}$} \\
\hline & Female & 101 & 15.80 & 2.967 & \\
\hline \multirow[t]{2}{*}{ Service quality } & Male & 151 & 72.40 & 10.661 & \multirow[t]{2}{*}{$2.819 *$} \\
\hline & Female & 101 & 68.08 & 13.587 & \\
\hline
\end{tabular}

$* 0.05$ level of significance

Table-3: ANOVA test for the difference in the perceived service quality and its dimensions for HDFC Bank customers on the basis Age

\begin{tabular}{|c|c|c|c|c|c|}
\hline ANOVA & & & & & \\
\hline & AGE & Sum of Squares & Df & Mean Square & $\mathrm{F}$ \\
\hline \multirow[t]{3}{*}{ Tangibility } & Between Groups & 147.928 & 3 & 49.309 & 4.259* \\
\hline & Within Groups & 2870.973 & 248 & 11.577 & \\
\hline & Total & 3018.901 & 251 & & \\
\hline \multirow[t]{3}{*}{ Reliability } & Between Groups & 90.741 & 3 & 30.247 & 2.099 \\
\hline & Within Groups & 3573.589 & 248 & 14.410 & \\
\hline & Total & 3664.329 & 251 & & \\
\hline \multirow[t]{3}{*}{ Responsiveness } & Between Groups & 189.070 & 3 & 63.023 & 9.504* \\
\hline & Within Groups & 1644.497 & 248 & 6.631 & \\
\hline & Total & 1833.567 & 251 & & \\
\hline \multirow[t]{3}{*}{ Assurance } & Between Groups & 38.767 & 3 & 12.922 & 1.662 \\
\hline & Within Groups & 1928.312 & 248 & 7.775 & \\
\hline & Total & 1967.079 & 251 & & \\
\hline \multirow[t]{3}{*}{ Empathy } & Between Groups & 85.089 & 3 & 28.363 & 3.274* \\
\hline & Within Groups & 2148.161 & 248 & 8.662 & \\
\hline & Total & 2233.250 & 251 & & \\
\hline \multirow[t]{3}{*}{ Service quality } & Between Groups & 915.594 & 3 & 305.198 & 2.119 \\
\hline & Within Groups & 35720.406 & 248 & 144.034 & \\
\hline & Total & 36636.000 & 251 & & \\
\hline
\end{tabular}

$* 0.05$ level of significance

5.4 Difference in the perceived service quality and its dimensions for HDFC Bank customers on the basis of Income

Table-4 depicts one way ANOVA test among customers of different income groups for various dimensions of service quality. The calculated value of $\mathrm{F}$ is more than the tables value for all the dimensions of service quality, 
hence the variance in the mean values of the sample is significant. Thus the hypothesis $\mathrm{H} 1.3$ for significant difference based on Income was accepted for service quality and its five dimensions.

Table-4: ANOVA test for the difference in perceived service quality and its dimensions for HDFC Bank customers on the basis of income

\begin{tabular}{|c|c|c|c|c|c|}
\hline \multicolumn{6}{|l|}{ ANOVA } \\
\hline & Annual Household Income & Sum of Squares & Df & Mean Square & F \\
\hline \multirow[t]{3}{*}{ Tangibility } & Between Groups & 151.540 & 3 & 50.513 & $4.369 *$ \\
\hline & Within Groups & 2867.361 & 248 & 11.562 & \\
\hline & Total & 3018.901 & 251 & & \\
\hline \multirow[t]{3}{*}{ Reliability } & Between Groups & 256.186 & 3 & 85.395 & $6.214 *$ \\
\hline & Within Groups & 3408.143 & 248 & 13.743 & \\
\hline & Total & 3664.329 & 251 & & \\
\hline \multirow[t]{3}{*}{ Responsiveness } & Between Groups & 175.691 & 3 & 58.564 & $8.760 *$ \\
\hline & Within Groups & 1657.877 & 248 & 6.685 & \\
\hline & Total & 1833.567 & 251 & & \\
\hline \multirow[t]{3}{*}{ Assurance } & Between Groups & 73.958 & 3 & 24.653 & $3.229 *$ \\
\hline & Within Groups & 1893.122 & 248 & 7.634 & \\
\hline & Total & 1967.079 & 251 & & \\
\hline \multirow[t]{3}{*}{ Empathy } & Between Groups & 126.098 & 3 & 42.033 & $4.947 *$ \\
\hline & Within Groups & 2107.152 & 248 & 8.497 & \\
\hline & Total & 2233.250 & 251 & & \\
\hline \multirow[t]{3}{*}{ Service quality } & Between Groups & 2572.437 & 3 & 857.479 & $6.243^{*}$ \\
\hline & Within Groups & 34063.563 & 248 & 137.353 & \\
\hline & Total & 36636.000 & 251 & & \\
\hline
\end{tabular}

$* 0.05$ level of significance

5.5 Difference in the perceived service quality and its dimensions for HDFC Bank customers on the basis of Education

Table-5 depicts the Analysis of Variance based on education for service quality and its dimensions. The calculated value of $\mathrm{F}$ is less than the table value for all dimensions of service quality. Hence, H1.4 for significant difference in the perceived service quality and its various dimensions for the HDFC Bank customers on the basis of educational backgrounds was not accepted.

Table-5: ANOVA test for the difference in the perceived service quality and its dimensions for HDFC

Bank customers on the basis of education:

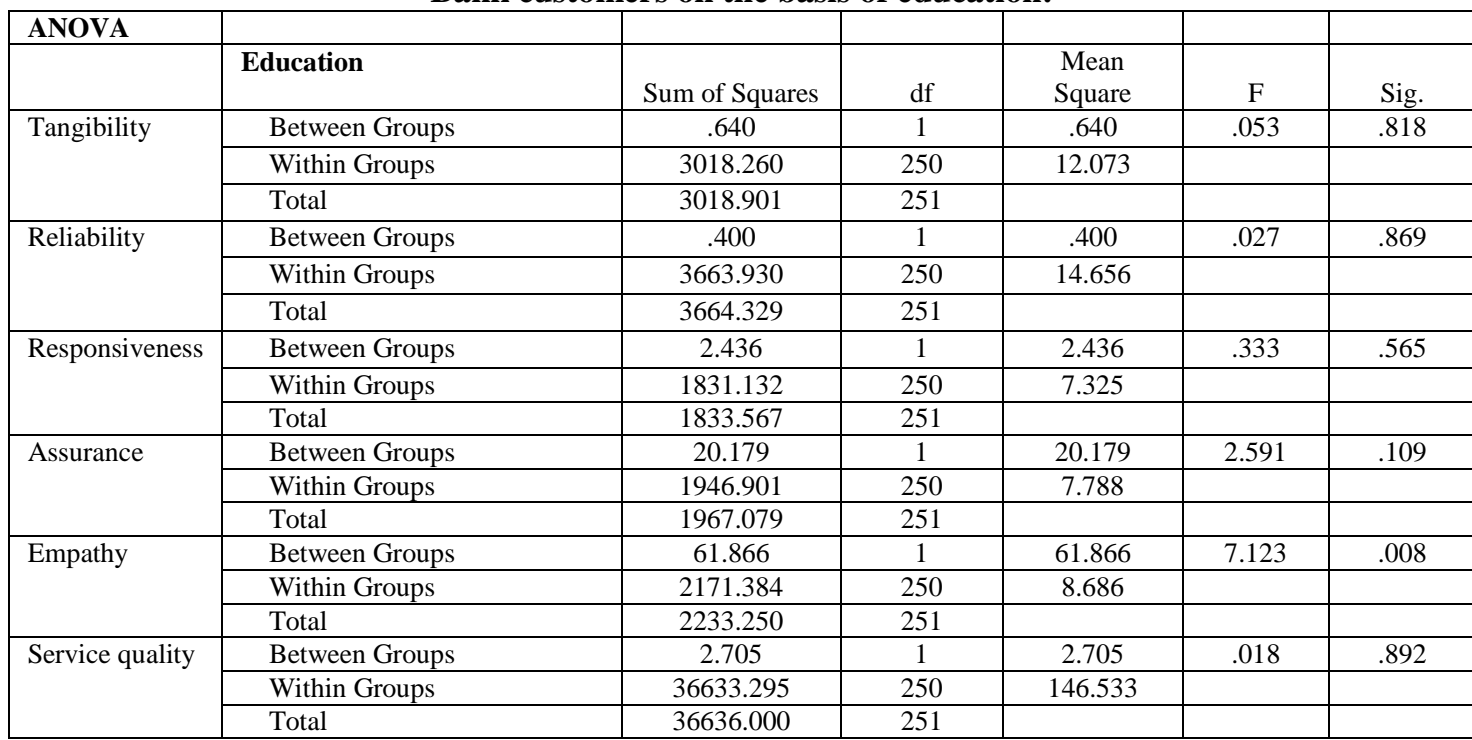


5.6 Difference in the perceived service quality and its dimensions for HDFC Bank customers on the basis of Occupation

Table-6 depicts the Analysis of Variance based on occupation for service quality and its dimensions. The calculated value of $\mathrm{F}$ is more than the table value for tangibility only. Hence, H1.5 for significant difference based on occupation was accepted only for the tangibility dimension of service quality.

Table-6 ANOVA test for the difference in the perceived service quality and its dimensions for HDFC Bank customers on the basis of occupation:

\begin{tabular}{|c|c|c|c|c|c|}
\hline \multicolumn{6}{|l|}{ ANOVA } \\
\hline & Occupation & Sum of Squares & Df & Mean Square & $\mathrm{F}$ \\
\hline \multirow[t]{3}{*}{ Tangibility } & Between Groups & 111.020 & 3 & 37.007 & $3.156 *$ \\
\hline & Within Groups & 2907.881 & 248 & 11.725 & \\
\hline & Total & 3018.901 & 251 & & \\
\hline \multirow[t]{3}{*}{ Reliability } & Between Groups & 36.684 & 3 & 12.228 & .836 \\
\hline & Within Groups & 3627.646 & 248 & 14.628 & \\
\hline & Total & 3664.329 & 251 & & \\
\hline \multirow[t]{3}{*}{ Responsiveness } & Between Groups & .303 & 3 & .101 & .014 \\
\hline & Within Groups & 1833.265 & 248 & 7.392 & \\
\hline & Total & 1833.567 & 251 & & \\
\hline \multirow[t]{3}{*}{ Assurance } & Between Groups & 15.061 & 3 & 5.020 & .638 \\
\hline & Within Groups & 1952.018 & 248 & 7.871 & \\
\hline & Total & 1967.079 & 251 & & \\
\hline \multirow[t]{3}{*}{ Empathy } & Between Groups & 23.322 & 3 & 7.774 & .872 \\
\hline & Within Groups & 2209.928 & 248 & 8.911 & \\
\hline & Total & 2233.250 & 251 & & \\
\hline \multirow[t]{3}{*}{ Service quality } & Between Groups & 354.403 & 3 & 118.134 & .807 \\
\hline & Within Groups & 36281.597 & 248 & 146.297 & \\
\hline & Total & 36636.000 & 251 & & \\
\hline
\end{tabular}

$* 0.05$ level of significance

5.7 Difference in the perceived service quality and its dimensions for HDFC Bank customers on the basis of Marital Status

To find out whether there is any difference in the perception of married and unmarried customers of HDFC Bank independent t-test was performed. The t-test (Table 7) indicated that there was a significant difference in the perception of married and unmarried customers for overall service quality $(\mathrm{t}=2.268)$ and its responsiveness dimension ( $\mathrm{t}=5.094)$. Thus Hypothesis H1.6 for significant difference based on marital status was partially accepted.

Table-7: T-Test for difference in the perceived service quality and its dimensions of HDFC Bank customers on the basis of marital status

\begin{tabular}{|l|l|c|c|c|c|}
\hline \multicolumn{2}{|c|}{ Marital Status } & $\mathrm{N}$ & Mean & Std. & t-value \\
\hline \multirow{3}{*}{ Tangibility } & Married & 164 & 15.63 & 3.241 & \multirow{2}{*}{1.411} \\
\cline { 2 - 5 } & Unmarried & 88 & 14.99 & 3.840 & \\
\hline Reliability & Married & 164 & 19.57 & 3.742 & \multirow{2}{*}{0.088} \\
\cline { 2 - 5 } & Unmarried & 88 & 19.52 & 3.986 & \\
\hline Assurance & Married & 164 & 8.03 & 2.885 & \multirow{2}{*}{$\mathbf{5 . 0 9 4}^{*}$} \\
\cline { 2 - 5 } & Unmarried & 88 & 6.30 & 1.870 & \\
\hline Empathy & Married & 164 & 11.88 & 2.797 & \multirow{2}{*}{1.441} \\
\cline { 2 - 5 } & Unmarried & 88 & 11.35 & 2.788 & \multirow{2}{*}{1.615} \\
\hline Service quality & Married & 88 & 16.80 & 2.567 & \multirow{2}{*}{$\mathbf{2 . 2 6 8 *}$} \\
\cline { 2 - 5 } & Unmarried & 164 & 71.92 & 10.833 & \\
\cline { 2 - 5 } & Married & 88 & 68.33 & 13.884 & \\
\cline { 2 - 5 } & Unmarried & & & & \\
\hline
\end{tabular}

*0.05 level of significance

\section{Conclusion}

There was a significant difference in the perception of service quality and its dimensions for the private sector bank customers for different categories of demographic factors. The perception of male and female customers varied significantly for the overall service quality and its dimensions- reliability, responsiveness, assurance and empathy. It was found that the male customers had a more positive perception of service quality 
as compared to the female counterparts. The differences on the basis of age were significant for tangibility, responsiveness and empathy. The high mean scores of the older age groups for tangibility and empathy indicated that they had a more positive perception about the banks visually appealing facilities and personal attention they got from the staff. Different income groups varied significantly for their perception of the tangibility, reliability, responsiveness, assurance and empathy dimensions of the service quality of the HDFC bank. It was observed that in the HDFC Bank the higher income customers had a more positive perception regarding the overall service quality as compared to the lower income groups. There was a significant difference in the perception of married and unmarried customers for overall service quality. The married customers had a more positive perception of the overall service quality than their unmarried counterparts.

Thus, this present research concluded that service quality is one of the most important factors in the private sector banks. The finding reinforces the need for banks managers to place an emphasis on the underlying dimensions of service quality and take into account the moderating effect of demographics. The managers should periodically assess and monitor service quality in their banks and recognize its importance in developing and maintaining enduring relationship with their customers as crucial parameters leading to increased performance.

\section{References}

[1] Slu, N. YM \& Mou, JCW (2003), “A study of service quality in Internet Banking”, BRC Working papers May 2003,Hong Kong Baptist University

[2] Parasuraman, A., Zeithaml, V. A., \& Berry, L. L. (1988). SERVQUAL: A multiple-item scale for measuring consumer perceptions of $\quad$ service quality, Journal of Retailing, 64 (1), p.12-40.

[3] Cronin, J.J. and Taylor, S.A. (1992). Measuring service quality: a re-examination and extension. Journal of Marketing, 56, 55-68.

[4] Gronroos, C. (1984), "A service quality model and its marketing implications", European journal of marketing, 18 (4), $36-44$ Haywood-Farmer, J. (1988), "A conceptual model of service quality" International journal of operations and production management, 8 (6) 19-29

[5] Siu, N. \& Cheung, J. (2001) 'A measure of retail service quality', Marketing Intelligence \& Planning, 19 (2), pp. 88-96.

[6] Kang Gi-Du, James Jeffrey, (2004) "Service quality dimensions: an examination of Grönroos's service quality model", Managing Service Quality, Vol. 14 Iss: 4, pp.266 - 277

[7] Chi Cui, C., Lewis, B.R. \& Park, W. (2003). Service quality measurement in the banking sector in South Korea. International Journal of Bank Marketing, 21, 191-201

[8] Wilson A., Zeithaml V.A., Bitner M.J., Gremler D.D. (2008) Services Marketing, McGraw-Hill Education

[9] Badri, M.(2003) The Measurement of IT Centers Service Quality at the Institutions of Higher Education in the UAE, Proceedings of the Fourth Annual Research Conference at the UAE University, Al-Ain, 27-29 (April)

[10] Curry, A. \& Sinclair, E. (2002) 'Assessing the quality of physiotherapy services using Servqual ', International Journal of Health Care Quality Assurance, 15 (5), pp. 197-205.

[11] Avkiran, N.K. (1994). Developing an instrument to measure customer service quality in branch banking. International Journal of Bank Marketing, $12,10-18$.

[12] Wang Y. \& Hing-Po L. (2002.) Service quality, customer satisfaction and behaviour intentions: Evidence from China's telecommunication industry, 4(6), 50-60.

[13] Huseyin Arasli, Salime-Smachi and Salih Turan Katircioglu,(2005).Customer Service Quality in the Derek Cypriot Banking Industry. Managing Service Quality, 15(1): 41-56.

[14] Zanna van Dun, Josee Bloemer and Jorg Henseler ,2009, Perceived customer contact centre quality: conceptual foundation and scale development, The Service Industries Journal, ISSN 0264-2069, 2009-10, 1-17

[15] Yaghi Derar Shaker (2010), A Customised Scale for Measuring Retail Service Quality in a College Shop: A Context Specific Approach, thesis, Newcastle Business School June 2010.

[16] Rai, R. (2009) "Service quality gap analysis in Indian bank: An empirical study" Paradigm, 13 (2), July-dec, 29-35

[17] Kumar, S. A., Mani, B. T., Mahalingam, S., and Vanjikovan, M. (2010). Influence of Service Quality on Attitudinal Loyalty in Private Retail Banking: an empirical study. IUP Journal of Management Research, 9(4),21-38.

[18] Negi, R. (2009). Determining customer satisfaction through perceived service quality: A study of Ethiopian mobile users, International Journal of Mobile Marketing;4(1),31-38.

[19] Elanain, H. (2003) Staff Perceptions of Service Quality in Egyptian Commercial Banks: An Internal and External Perspective. Loughborough University.

[20] Siu, N. \& Cheung, J. (2001) 'A measure of retail service quality', Marketing Intelligence \& Planning, 19 (2), pp. 88-96

[21] Ganesan-Lim, C., Russell-Bennett, R. \& Dagger, T. (2008) 'The impact of service contact type and demographic characteristics on service quality Perceptions ', Journal of Services Marketing, 22 (7).

[22] Paulins, V. (2005) 'An analysis of customer service quality to college students as influenced by customer appearance through dress during the in-store shopping process', Journal of Retailing and Consumer Services, 12, pp. 345-355.

[23] Meng, J., Summey, J., Herndon, N. \& Kwong, K. (2009) 'Some retail service quality expectations of Chinese shoppers', International Journal of Market Research, 51 (6), pp. 773-796.

[24] Spathis Charalambos, Eugenia Petridou, Niki Glaveli, (2004) "Managing service quality in banks: customers' gender effects", Managing Service Quality, Vol. 14 Iss: 1, pp.90-102

[25] Ogden, J. \& Ogden, D. (2005) Retailing: Integrated Retail Management. Boston: Houghton Mifflin Company.

[26] Kent, T. \& Omar, O. (2003) Retailing. New York: Palgrave Macmillan.

[27] Kotler, P. \& Armstrong, G. (2010) Principles of Marketing. 13th edn. London: Pearson. 